\title{
Impact of Relations between the Electorate and the Political Parties in Terms of Ideological Profiling
}

\author{
Roland Lami \\ European University of Tirana \\ Tirana, Albania \\ rolandlami@yahoo.com
}

\section{Doi:10.5901/mjss.2014.v5n2p341}

\section{Abstract}

Social, political and economic reality in Albania has led to the debate on policy issues of left and right specter at a specifically theoretical and practical level. In order to shed light on the vagueness of ideological structuring of Albanian main parties, a survey was undertaken. This survey would examine how the electorate of Tirana perceived the relation between the Albanian politics and ideology. At the same time, the survey would assess the behavior of the voting electorate in relation to this structuring of the Albanian political parties. The results of such a sociological research are very important because this perception of Tirana electorate has a great impact on its voting behavior. Moreover, one third of the electorate of the Republic of Albania lives in Tirana, having thus a very significant effect on the general opinion of the Albanian society.

Keywords: ideology, left, right, political parties, social context

\section{Theoretical Framework}

From the theoretical standpoint, ideological vagueness is explained based on the structural-functionalist perspective. Interdependencies - among the "deeply social" factors and the political discourse - shed light on the vagueness of ideology. This intends to better understand the circumstances that condition the political subjects to represent social categories, part of the social context, and to highlight the implications related to the creation of political identity, implications arising from the type of discourse of the political actor.

This interdependence between units within the structure is limited by the concept of the ideology of the political parties within a specified period of time. As long as the politics is associated with many aspects of society and decisions for distribution - by means of authority - of values in society are influenced by economic, cultural, social, geographical, psychological factors, etc., (Almond, 1968., Powell, 2000, Easton, 1965) , it is important that, in the framework of empirical research, the dependent and independent variables should be clearly defined. This attempt is made with the intention of conducting a systematic analysis. In other words, "subjective reality should be viewed as conditional or it may be caused by the objective reality, and vice versa" (Eagelton, 1991: 34). Intentionally, for many scholars of political science, concepts of "political structure" and "political function" are employed as analytical tools to present the mode of existence and development of political systems, especially as supporting instruments to compare them (Almond, 1968., Easton, 1965).

Giving emphasis to the analysis of structure differentiates the functional structuralism from structural functionalism (Kiss 1990:75 - 89). However, on the other hand, political-state structures and political-social structures are considered as part of a system. In this regard, there is not a one-sided and simultaneous determination, in the sense that a first phenomenon produced by the interaction between the components within the system defines or causes a second phenomenon; the latter defines or causes a third one, and so on (Beyma, 1992: 95). Determinability is reversible as the first phenomenon defines the second one, but the second also defines the first etc. So, all political actors at the micro level and units at macro level mutually affect each-other (Merton, 1967).

\section{Methodology}

Defining the problem: Under the Tirana electorate's view, there is not a clear relation between politics and ideology. In particular, programs and actions of political parties are not structured by ideological "matrixes".

The study raises two research questions: 
- How is structured the relation between politics and ideology to the main Albanian parties?

- If the programs of political parties do not comply with the requirements conditioned by the affiliations in the ideological wings, then will that part of the people ideologically and traditionally voting for them be inclined to change their minds?

Based on assumption and basic hypothesis, a number of implications related to conditional judgment are logically derived, in order to allow direct and indirect empirical testing of the basic hypothesis. Depending on the results of this testing, it will be judged whether to acknowledge the basic and indirect assumption of the study hypothesis.

In this framework, the following implications are deducted:

Implication 1: less do representative of special interests become political parties, least do social groups identify themselves with political parties

Implication 2: less do the groups attempt to position themselves in doctrinal terms, more difficult is to represent the needs and demands of the political parties

Implication 3: less unclear is the electorate for the "left" and "right" doctrines, least shall the political stances of parties be conditioned by the affiliations in the ideological wings

Implication 4: more the political parties articulate the interests of social groups, implying standard reforms or generalizing policies, most are they unable to represent these social groups

To realize the latter, the methodological method was pursued:

Defining the Sampling: Out of 11 constituencies of Tirana, corresponding to 11 mini-municipalities, 4 constituencies were selected by sampling methods with clusters and causal-sampling methods. Specifically, following a random selection, zone 2 (110 respondents), zone 3 (101 respondents), zone 6 (100 respondents) and zone 7 (99 respondents) were chosen. Further, again with a combination of quota- and causal-sampling, four streets for each constituency were chosen. In these streets, a quota sampling was implemented (based on age groups and gender), as the prepared questionnaire included subtle questions related to parties, their programs, the political wing of the parties, respondents etc. During two days, a total number of 410 respondents were interviewed on 5 different age groups (18-25 years, $26-35$ years, $36-45$ years, $46-55$ years and above 55 years); from this group, about $49 \%$ were women and nearly $51 \%$ were male.

Later, a database was established and the data collection was organized. The database was unified using a program called SPSS.16. Afterwards, the appropriate statistical elaboration took place - including the frequencies tables, different graphics and cross tabulations - in order to find out the possible statistical associations of the variables, which were defined to empirically test the above mentioned implications.

\section{Results and Discussions}

The study shows that the majority of respondents, about $76.5 \%$, stated that they support a specific political wing; nearly $64 \%$ of them report that they are familiar to party programs; $50 \%$ of them say that people generally are able to find out whose political wing represents a party program while $45.6 \%$ say that are not in a position to know such a fact. These data indicate that the electorate votes referring to their political ideas.

These ideas are frequently manifested in the form of opinions and judgments when the people analyze the programs and the behavior of political parties. These ideas help people position the three main political parties - DP, SP and SMI (Democratic Party, Socialist Party and Socialist Movement for Integration) from the ideological standpoint. For instance, when they are asked: "As far as you know, which ideological wing represent DP?", $5.4 \%$ of respondent say that DP is positioned in the left camp and $82.9 \%$ state that DP is positioned in the right wing (ratio $1: 15.3$ positioning DP in the right wing and $3.4 \%$ do not position it in no wing). So $9 \%$ of respondents do not perceive that DP is a party of the right wing, which lead us to believe that there is some vagueness regarding the ideological identity of this party.

For the same question, but concerning SP, we have the following results: $\mathbf{8 2 . 9} \%$ of respondents categorize SP a party of the left wing, $4 \%$ state that it is a party of the right wing, while $3.7 \%$ do not position SP in any political wing. The ration between the identification as a left or right force is $10.8: 1$, considerably in favor of its identification as a left force. However, there is a small group of $7.7 \%$ that do not position SP as a left political force, which means that even for this party there is some vagueness regarding the ideological identity of this party.

When the same question is made for SMI, $32 \%$ of respondents state that SMI is positioned in the left, $23.2 \%$ state that it is position in the right and $22.7 \%$ state that it does not represent any political wing. So, those who do not classify this party in the left are $45.5 \%$ or 1.4 times more than those positioning it in the left wing (where this party pretends it belong to). 
What we draw out of these data is the fact that the two main parties SP and DP - through electorate's perception of Tirana - are positioned in ideological wings which respective parties claim that they belong to. Even though SMI is presented as a left wing party, the electorate perceives it as a party without a clear ideological profile. This perception towards SMI is somewhat explained by the following factors: a) its positioning from a typical left wing in opposition to sharing power with the right wing after the 2009 elections, b) coalition of DP with SMI in local elections in 2013, c) presentation in the 2013 election campaign with a program with elements of center left and center right.

Another aspect of the survey shows the public perception for the relation between the political program and the ideological wing. As it turns out, most of respondents are aware of the programs of political parties and are able to tell the difference between the political program and the ideological wing for DP, SP and SMI. When it comes to the question "Does the right electorate notices discrepancies between the DP program and the right ideological wing this party pretends to belongs to?", $26.3 \%$ of respondents who identify DP as a party of the right, do not think (to the degree More, No, and None) that the electorate of the right of DP notices discrepancies between the DP program and the right ideological wing this party pretends to belongs to. $25.5 \%$ of respondents, who identify DP as a party of the right, think that the electorate of the right of DP notices discrepancies between the DP program and the right ideological wing this party pretends to belongs to.

Regarding SP, about $30.2 \%$ of the respondents who identify SP as a party of the left wing, think that (in a high degree or completely) the electorate of the left of SP notices discrepancies between the SP program and the right ideological wing this party pretends to belongs to, while $18.7 \%$ of them do not think (to the degree More, No or None) that the electorate of the left of SP notices discrepancies between the SP program and the right ideological wing this party pretends to belongs to.

Regarding SMI, $31 \%$ of the respondents who identify this force as a party of left wing, $20 \%$ of them notice discrepancies between its program and political wing, while $8 \%$, who identify this force as a party of left wing, do not notice discrepancies between its program and political wing (in total 24\%).

Based on these data, we can conclude that the three parties show differences for the relation between programsideological wings.

Another important aspect of the survey relates to the electorate behavior when there is an inconsistency between the program and ideological wing. About $28.9 \%$ of respondents who notice a discrepancy between the program and ideological wing of the SP (somewhat, in a high degree and completely), think that SP electorate shall react to this situation by not voting, whereas $20.6 \%$ of respondents notice this discrepancy, but do not want to vote against this political force. Meanwhile, $9.1 \%$ of respondents who notice a discrepancy between the program and ideological wing of the DP (in a high degree and completely), think that SP electorate shall react to this situation by not voting, while $13.5 \%$ of respondents notice this discrepancy, but do not want to vote against this political force. Regarding SMI, $15.3 \%$ of respondents who declare that they generally notice a discrepancy between the program and ideological wing, are inclined to vote against it (at the levels: yes, in a high degree and completely). [This is that part of respondents who think based on ideology in relation with the voters behavior.] $19.4 \%$ of respondents who

notice a discrepancy, do not want to vote against SMI. It results that these data show an ideological stance for SP supporters and a pragmatist stance for DP and SMI supporters. This difference in the electorate behavior can somewhat be explained when we refer to the fact that a specific social category perceives SP as successor (or inheritor) of Labor Party of Albania.

\section{Conclusions}

The above data significantly affect the way how political parties structure their programs from the ideological point of view. It is important to note that these parties have a considerable part of the electorate that evaluates them for the results rather than the ideological content they represent. In a sense, pragmatic approach predominates over the ideological one, making it difficult for political parties to articulate ideological content. But, this reality creates a two-way effect. Less representative of special interests do the political parties become, least do the social groups identify themselves with political parties. On the other hand, less do the social groups identify themselves, more difficult becomes the representation of their needs from the political parties. This means that, if the political parties articulate the interests of social groups by implying standard reforms or generalized policies, they are unable to really represent these social groups. Over the years, this vicious circle has created fluidity of partisan identities and social groups, and therefore the relationship between them has been unstable and unclear. The latter often establish politics. Not only that. In many cases they form even the political behavior at the expense of ideological structuring of political parties 


\section{References}

Almond, G.A ( 1968) Comparative Political Systems, Macridis : Dorsey Press.

Bell, D. (2000) The End of Ideology, Harvard University Press.

Bobbio, R. (1997) Majtas dhe Djathtas, Tiranë: Arbri .

Bugajski, J. (2002) Political Parties of Eastern Europe, London \& New York: Westview Press.

Easton, D. (1965) A Framework for Political Analysis, Englewood Kliffs, N.J. Prentice Hall.

Extmann, R. (2007) Democracy: Problems and Prespectives, Edinburgh: Edinburgh University Press.

Eagelton, T. (1991) Ideology, New York: Verso.

Freeden, M, (2003) Ideology: A very short introduction, Oxford University Press.

Fuga, A. (2003) Majtas jo djathtas, Tiranë: Ora.

Farrell, M.D. (1998) Political Parties as Campaign Organizations, Manchester: University of Manchester.

Feraj, H. ( 2006) Skicë e mendimit politik shqiptar, Tiranë: Pegi

Pëllumb, S. (2009) Pluralizmi politik, Tirane: IS.

Merton, R. ( 1967) On Theoretical Sociology, New York: The Free Press.

Mule, R. (2004) Political Parties, Games and Redistribution, London: Cambridge University Press.

Laclau, E. (2005) On Populisy Reason, London - New York: Verso.

Heywood, A. (2007) Political ideologies, an introduction. New York: Palgrave Macmillan.

Krasniqi, A. ( 2007) Partitë Politike në Shqipëri ( 1920 - 2006), Tiranë:ISHSP.

Tarifa, F \& Krisafi, K \& Tarifa, E. (2009) Paradigma e tranzicionit demokratik, Tiranë: Ombra GVG.

Freire, A. (2006) Bringing Social Identities Back In: The Social Anchors of Left-Right

Orientation in Western Europe. International Political Science Review 27: 359-78.

Huber, J. (1989) Values and Partisanship in Left-Right Orientations: Measuring Ideology. European Journal of Political Research 17: $599-621$. 